\title{
Community Respond to Waste Treatment Base on 3R (Reduce, Reuse and Recycle) in The Settlement Environment of Moronge Village, Moronge District, Talaud Islam Regency
}

\author{
Nixon J. Sindua*, Jolanda E. Kaihatu \\ Department of Geography Education, Faculty of Social Sciences, Manado State University, Indonesia
}

\begin{abstract}
This study aims to determine the community's response to waste management based on $3 \mathrm{R}$ (Reduce, Reuse and Recycle) in the residential environment of Moronge Village, Moronge District. A descriptive quantitative research method was used by determined $25 \%$ of the population sample from 30 families. The result shows, The reducing of waste by $80 \%$ of respondents think that the condition of waste in the residential environment of Moronge Village, Moronge District is very concerning, an attempt to reuse waste that can still be used for the same or different functions from $83.3 \%$ of respondents agree if there is a part of the waste that can still be used and The activity to reprocess or recycle that $86.7 \%$ of respondents agree to utilize waste that can still be used in the form of recycling.
\end{abstract}

Keywords: Waste Treatment, Reduce, Reuse and Recycle, Community Respond

\section{Introduction}

Indonesia is very strategically located, namely in the tropics, flanked by two continents (Asia and Australia) and two oceans (India and the Pacific). This strategic location makes Indonesia a country rich in natural resources. Maritime tourism, aquaculture, mining and settlements are some examples of high-value economic potential. No wonder the coastal area becomes an attraction for all parties to manage and use it from an economic and political perspective. Coastal areas are land/dry land routes adjacent to the sea, where the environment and land use directly affect the marine environment, and vice versa. A coastal area is a path that limits land with the sea or lakes of varying widths. [1]).

Indonesia's rich and diverse coastal and marine areas have been used by the Indonesian people as one of the main sources of food ingredients, especially animal protein, for centuries. Meanwhile, the wealth of hydrocarbons and other minerals found in this area has also been utilized to support national economic development. In addition to providing these resources, Indonesia's coastal and marine areas have various other functions, such as transportation and ports, industrial areas, agribusiness and agro-industry, recreation and tourism, as well as residential areas and waste disposal sites [2].

Waste is unwanted residual material after the end of a process. Garbage is a man-made concept, in natural processes there is no waste, only immovable products. Garbage can exist in any phase of matter: solid, liquid, or gas. When released in the last two phases, especially gas, waste can be said to be an emission. Emission is usually linked with pollution. In human life, large amounts of waste come from industrial activities (also known as waste), such as mining, manufacturing, and consumption. Almost all industrial products will become waste at some time, with the amount of waste roughly similar to the amount of consumption [3].

With the more rapid and increasing quality of the population, the accumulation of this waste has not been resolved until now. The Moronge people feel restless and uneasy about their environment which is really worrying, because many people are not comfortable with their situation. However, the Moronge people of the Moronge village are also not aware and realize that all this happened because of their own actions and actions.

This area is always growing with the rapid development carried out by various parties. These parties indirectly cause environmental damage due to activities carried out on land and at sea. This makes the coastal ecosystem an ecosystem that is vulnerable to natural and artificial damage and destruction [4]. Handling these problems wisely and appropriately can reduce or prevent the damage that occurs. This report presents the environmental problems of the Moronge village settlements caused by natural and human factors

\footnotetext{
* Corresponding author : nixonsindua@unima.ac.id
} 
along with the appropriate solutions to the problems faced.

Garbage is a very influential thing and has a negative impact on the health and sustainability of the community in the residential environment (Moronge Village Moronge Community). The pile of garbage that occurs in this area is really very worrying, because there is no awareness of the local community to prevent and overcome this problem. The Village Government also does not see this as an obligation that must prevent and preserve the environment in which the Moronge community lives in Moronge villages.

Garbage causes various diseases of diarrhea, cholera, typhus spread quickly because viruses that come from waste with improper management can mix with drinking water. Dengue fever (haemorhagic fever) can also increase rapidly in areas with inadequate waste management, Fungal diseases can also spread (eg skin fungus), Diseases that can spread through the food chain. One example is a disease transmitted by tapeworms (taenia). These worms previously entered the digestive tract of livestock through their food in the form of food waste/garbage [5]. So waste is very detrimental to human life which includes destroying the existing environment and also has a negative impact on health.

\section{Research Methods}

This research is quantitative descriptive. This study adopts one variable, namely to determine the community's response to waste management based on 3 $\mathrm{R}$ (Reduce, Reuse and Recycle) in the residential area of Moronge Village, Talaud Islands Regency. The community response variable to the 3R-based waste management (Reduce, Reuse and Recycle) is the response of the community or residents in the research location regarding the 3R-based waste management (Reuduce, Reuse and Recycle).

The population in this study is the community in the residential area of Moronge Village as the object of research. The research sample is representative of the population determined at random or random sampling, then $25 \%$ of the population is determined so the sample is 30 families. This research is field research (field research), so in collecting data used several techniques, namely observation, interviews, questionnaires or questionnaires and documentation.

\section{Result and Discussion}

1. The condition of waste in residential areas is very alarming. 20 people or about $66.7 \%$ think that the condition of the waste in their environment is very concerning, and 7 people or about $23.3 \%$ think that it is apprehensive. Thus, about $80 \%$ of respondents think that the category is concerning to very concerning about the condition of the waste in the environment.

2. Support all efforts made to prevent the accumulation of waste. 15 people or around $50.0 \%$ think they strongly support the various efforts made to prevent the accumulation of garbage, while 13 people or around $43.3 \%$ think they support it, and there are 2 people or $6.7 \%$ who quite support the effort. Thus there are about $93.3 \%$ of respondents think they support to strongly support the efforts made to prevent the accumulation of waste.

3. Public awareness about the importance of environmental cleanliness is very important to be instilled through counseling activities. 16 people or about $53.3 \%$ think they strongly support the various efforts made to prevent the accumulation of garbage, while 13 people or around $43.3 \%$ think they support it, and there are 2 people or $6.7 \%$ who quite support the effort. Thus, there are about $93.3 \%$ of respondents think they support to strongly support the existence of counseling guidance activities in order to instill awareness of environmental cleanliness.

4. The activity of utilizing existing waste, especially those that can still be used, is very important to do. 13 people or about $43.3 \%$ think strongly agree with the statement that it is possible to use waste that can still be used of course through a process, while 12 people or around $40.0 \%$ think they agree, and there are 5 people or $16.7 \%$ who do not. agree if you can reuse waste that can still be used. Thus there are about $83.3 \%$ of respondents agree if there is a part of waste that can still be used, of course after going through a certain process, so that there is a part that has been categorized as waste that can still be used for certain uses.

5. Efforts are being made to utilize waste that can still be reused. 14 people or around $46.7 \%$ of the opinion strongly agree if there are efforts or efforts made to utilize waste that can still be used, while 12 people or around $40.0 \%$ think they agree, and there are 4 people or $13.3 \%$ who do not. agree if there is an attempt to reuse the waste that can still be used. Thus there are about $86.7 \%$ of respondents agree if there are efforts or efforts made to utilize waste that can still be used.

6. With a lot of waste in the environment, recycling is an important activity in the context of waste management. 14 people or around $46.7 \%$ think strongly agree if there is an effort or effort made to utilize waste that can still be used, while 12 people or around $40.0 \%$ think they agree, and there are 4 people or $13.3 \%$ who do not. agree if there is an attempt to reuse the waste that can still be used. Thus there are about $86.7 \%$ of respondents agree if there are efforts or efforts made to utilize waste that can still be used.

7. Activities to reprocess or recycle waste in the environment for a need. 15 people or around $50.0 \%$ think that they strongly agree with the activities of reprocessing or recycling existing waste according to their needs, while 14 people or around $46.7 \%$ have the opinion that they agree with the activity of recycling waste, and there is 1 person or 3, 3\% who do not agree with waste recycling activities. Thus there are about $96.7 \%$ of respondents agree to 
strongly agree with the activity of recycling waste, because in reality waste still has its use if it is processed or recycled according to existing needs [6].

8. It is important to conduct guidance activities regarding the business of reprocessing existing waste or recycling waste. 18 people or around $60.0 \%$ think it is very important if there is a guidance activity to the community about the business of recycling waste, while 10 people or around $33.3 \%$ think they agree with the guidance activity about recycling waste, and there are 2 people or $6,7 \%$ who do not agree with the guidance activities regarding waste recycling. Thus there are about $93.3 \%$ of respondents agree to strongly agree with the guidance activities to the community about recycling waste, because in reality waste still has its use if it is processed or recycled according to existing needs.

9. Activities to reprocess existing waste according to need. 17 people or around $56.7 \%$ think it is very important to have activities to process waste according to their needs, while 10 people or around $33.3 \%$ think the importance of processing existing waste into useful objects, and 3 people or as much as $10.0 \%$ who think it is quite important to carry out waste processing activities according to their needs. Thus there are around $90.0 \%$ of respondents think it is important and even very important to carry out activities aimed at reusing existing waste according to their needs after going through a recycling process.

The condition or presence of waste in residential areas is very alarming. This is the opinion of the majority of the population who were respondents in this study. Most of the respondents or about $80 \%$ of respondents thought that the condition of waste in the residential environment of Moronge Village, Moronge District was very concerning. Respondents generally support all efforts made to prevent the accumulation of waste in the residential area of Moronge Village, Moronge District. Most or around $93.3 \%$ of respondents think they support to strongly support the efforts made to prevent the accumulation of waste [4]. In general, respondents stated that it is very important to instill awareness about environmental cleanliness through counseling activities for the community in Moronge Village, Moronge District. There are about $93.3 \%$ of respondents think the importance of guidance and counseling activities as an effort to instill awareness of the importance of environmental cleanliness.

Most of the respondents stated about the importance of utilizing waste that can still be used, of course, by going through a process that is carried out. There are about $83.3 \%$ of respondents agree if there is a part of waste that can still be used, of course after going through a certain process, so that there is a part that has been categorized as waste that can still be used for certain uses. Most of the respondents agreed and even strongly agreed with the efforts made to utilize waste that could still be used. There are about $86.7 \%$ of respondents agree if there are efforts or efforts made to utilize waste that can still be used. Because the reality is there is still garbage that can still be used.

Activities or businesses to recycle waste is an important activity to do. Where based on research data shows there are about $86.7 \%$ of respondents agree if there is an effort or effort made to utilize waste that can still be used in the form of recycling [7]. Most of the respondents strongly agree with the activities of reprocessing or recycling existing waste according to their needs. Where there are $96.7 \%$ of respondents agree to strongly agree with waste recycling activities, because in reality waste still has its use if it is processed or recycled according to existing needs. Most of the respondents thought that the importance of guidance activities on recycling waste. This is indicated by the data of $93.3 \%$ of respondents agree to strongly agree with the guidance activities to the community about recycling waste, because in reality waste still has its use if it is processed or recycled according to existing needs.

According to the majority of respondents, the activities carried out as an effort to recycle waste carried out so far are very important activities carried out as an effort to deal with waste. Where there are about $90.0 \%$ of respondents think it is important and even very important to carry out activities that aim to reuse existing waste according to their needs after going through a recycling process.

In general, it can be explained that the three activities, namely reduce, reuse and recycle, are important to do as an effort to deal with waste, including efforts to tackle waste problems, especially those in Moronge Village, Moronge District as a research area that focuses on waste management.

Reduce which is meant in this study, is an effort to reduce everything that causes waste, or in other words reduce is an action to prevent the occurrence of haphazard waste disposal and also as an action to prevent the accumulation of garbage.

Reuse which is meant in this study is an attempt to reuse waste that can still be used for the same or different functions. This shows an action or treatment taken to sort and select existing waste to get waste that can still be used.

Recycle which is meant in this research is an activity or business to reprocess or recycle. This refers to the actions taken to process the waste so as to produce goods of value.

The results of the study generally indicate that most respondents strongly agree with the activities to reduce the occurrence of waste, can reuse parts of the waste that are still allowed to be used or utilized, and strongly agree with waste recycling activities.

Respondents who live in the residential area of Moronge Village, Moronge District, are of the opinion that the heap can cause: an unpleasant environment, an unsightly environment, and a slum environment. Therefore, there needs to be an effort to handle waste that is carried out with 3 R Reduce, Reuse and Recycle actions.

So, the consequences caused by waste to the environment in general can be explained as less or unpleasant for the existing environment. The 
environment should be arranged or cleaned properly so that the environment becomes pleasant for anyone who is in the place or pleasant for anyone around the place.

Some of the people of Moronge Village think that the condition of the existing waste is very alarming, because of that the residents support various efforts to prevent the accumulation of waste, so that residents do reduce as an effort to reduce everything that causes waste. Most of the population responds to efforts to reuse waste that can still be used, so they support reuse activities. Most of the population gave a positive response to waste recycling activities, and residents considered it important to utilize waste through the recycling process.

\section{Conclusion}

The condition or presence of waste in residential areas is very alarming. This is the opinion of the majority of the population who were respondents in this study. Most of the respondents or about $80 \%$ of respondents thought that the condition of waste in the residential environment of Moronge Village, Moronge District was very concerning.

\section{Reference}

[1] A. Zulkarnaen, 'Identifikasi Sampah Laut (Marine Debris) Di Pantai Bodia Kecamatan Galesong, Pantai Karama Kecamatan Galesong Utara, Dan Pantai Mandi Kecamatan Galesong Selatan Kabupaten Takalar', Skripsi. Progr. Stud. Ilmu Kelautan, Dep. Ilmu Kelautan, Fak. Ilmu Kelaut. Dan Perikanan, Univ. Hasanuddin Makassar, 2017.

[2] F. Arif, Penanganan Sampah Pemukiman di Kawasan Pesisir Kota Makassar. Makassar: Universitas Hassanuddin, 2013.

[3] I. S. L. Tobing, 'Dampak sampah terhadap kesehatan lingkungan dan manusia', Makal. pada Lokakarya Aspek Lingkung. dan Leg. Pembuangan Sampah serta Sos. Pemanfaat. Sampah Organik sebagai Bahan Baku Pembuatan Kompos. Kerja sama Univ. Nas. dan Dikmenti DKI. Jakarta Juni, 2005.

[4] M. W. D. Matase, 'Perilaku Masyarakat Dalam Pengelolaan Lingkungan Di Wilayah Pesisir Desa Lero Kecamatan Sindue Kabupaten Donggala', J. Pendidik. Geogr., vol. 5, no. 1, 2017.

[5] M. al Gelbert, D. Prihanto, and A. Suprihatin, 'Konsep pendidikan lingkungan hidup dan" wall chart"', Buku Pandu. Pendidik. Lingkung. Hidup, PPPGT/VEDC, Malang, pp. 20-33, 1996.

[6] J. Sahil, M. H. I. Al Muhdar, F. Rohman, and I. Syamsuri, 'Sistem pengelolaan dan upaya penanggulangan sampah di Kelurahan DufaDufa Kota Ternate', BIOeduKASI, vol. 4, no. 2, 2016.

[7] M. Adi Winarta, 'Kebijakan Pengelolaan
Sampah dalam Upaya Mencegah Pencemaran Lingkungan Hidup di Kawasan Pantai Pasir Putih Kabupaten Situbondo'. UNIVERSITAS MUHAMMADIYAH JEMBER, 2017. 